\title{
NATIONAL ISSUES IN V. G. KOROLENKO'S ESSAYS
}

Viacheslav Nikolaevich Krylov ${ }^{1}$

Abstract: The article is devoted to the analysis of various documentary and journalistic works by V. G. Korolenko on the theme of the U.S. The material consists of both published and unpublished works during the lifetime of the writer (travel notes, articles, correspondence, etc.). The analysis allows us to see in the works of Korolenko not just ethnographic travel essays but profound reflections on the two images of the world, Russian and American, that include the assessment of the pace of technological progress, ideals of freedom, respect for the individual, attitude toward pragmatism, and individualism. The theme of national awareness on the background of European and American realities is considered to be essential in the work of Korolenko.

UDC Classification: 821.161.1, DOI: http://dx.doi.org/10.12955/cbup.v3.619

Keywords: dialogue, national, Russia, U.S., V. G. Korolenko, freedom, justice

\section{Introduction}

The proposed article is based on a theoretical idea shared by modern scholars that national identity is developed and preserved in cultural texts that create the identities through which Russia and Russian take the ever-changing forms (Anderson, 1993; National Identity in Russian Culture, 2004). According to Homi Bhabha, nation is "a system of cultural values" (Homi Bhabha, 1990). Russian literature becomes one of the leading components in the nation's self-reflection and development of the national imaginary. According to Russian literary tradition, journalism, along with fiction, is a significant form of understanding of a national identity. V. G. Korolenko ranks high among the rich and, yet to be fully studied, creative heritage of the journalistic thought of the Silver Age. Korolenko's speeches in support of ethnic minorities (the image of the Yakut people, essays about the Kishinev pogrom, consistent defense of the Jews in the "Beilis case," and protection of the Udmurt peasants accused of a ritual murder by the tsarist authorities "Multan case") will stay in the history of Russian thought forever. Being Ukrainian and Polish by origin, Korolenko perceived himself as a representative of Russian culture and, therefore, mainly reflected about Russia. The theme of Russia, its historic identity and its future, becomes one of the most controversial topics of Russian realism of the $19^{\text {th }}-20^{\text {th }}$ centuries along with the heated debates on national issues and national reflection.

Of course, the problem understanding Russia better could not have been carried out without the experience of the "foreign" world. There was hardly a "thick journal" of that time that did not publish all sorts of travel essays, ethnographic series of travel notes about the everyday life of different peoples. It is now a cultural axiom that in order to understand "your own" you have to understand the "foreign." A dialogue with the "others" allows one to find new hidden meanings in their own "word" and, ultimately, in a cultural text. This allows us to set theoretical identity through contrast and comparison. We who define "we" not only by looking at ourselves, but also by concluding how we are similar or different from "them" (Franklin \& Widdis, 2014).

The article will reveal the way the contradictory process was reflected in the documentary and journalistic reflection of North America in the works of a leading realist of the $19^{\text {th }}-20^{\text {th }}$ centuries V. G. Korolenko. In the analysis, we rely on the study the U.S. perception of Russian culture (Saul, 1991; Arustamova \& Kondakov, 2010).

\section{Reflections on the national theme in the American essays}

In 1893, Russian journal, Idea, sent V.G. Korolenko as a correspondent to the World Exhibition in Chicago. The journey via Europe to the U.S. was directly reflected in one of his most famous works, the story "Without a Language," as well as in other various autodocumentary texts-correspondence,

\footnotetext{
1 Viacheslav Nikolaevich Krylov, Institute of Philology and Intercultural Communication, Kazan (Volga Region) Federal University, krylov77@ list.ru
} 
notebooks (mostly unpublished during the writer's lifetime), travel essays, and political essays. Korolenko's letters, essays, and notebooks contain numerous comparisons of the U.S. and Russia. Below we will study and systematize them carefully.

While travelling around Europe (Finland), Korolenko already started thinking about the "special signs" of a Russian person, about the "passport" feeling that considerably differ the Russians from other nationalities. "The English, for example, be they either at home or abroad, are, primarily, what they call themselves. And if anyone dared doubt their 'individuality,' then the skeptic would have to bother himself by presenting evidence and grounds both for doubts and for the explanation of the others... Russian people, on the contrary, are always ready to prove their authenticity, and it is not surprising that a piece of paper containing the proof is called our 'type')" (Korolenko, 1923).

The theme of national awareness against the background of European and American realities will become permanent in all of Korolenko's works. Korolenko even reflects on the topic: “we, Russians, whatever class or line we may belong to, travel abroad with a special feeling. It can be a naive trust in the West or vice versa, a puffy 'patriotic' neglect, but still, in our first glance at free Europe, you can read the same question, 'Well, what do you have better than we do?' 'You've got freedom, the constitution and the republic'... 'Don't you have hunger, poverty or vices?'...” (Korolenko, 1923).

A suggestion of a landlady to educate Russian children in English families created a complex feeling that is expressed in a letter. On the one hand, the feeling of little jealousy ("education is fine here; I saw these beautiful girls who go to English schools, boys, ruddy and strong but also bouncy, cheerful, and lively, with excellent musculature and physical bearing, and I became a little jealous" (Korolenko, 1956)), and on the other hand, there is expressed a sense of fear for the fate of the Russian language. "Here, the children of Russian parents have become perfectly English; the boys do not say a word in Russian, the girls (much older) speak with a strong accent and laugh at the same time - their mother tongue seems ridiculous and wild to them! <...> But I shudder at the thought that my children would not understand my language, my thoughts, dreams, and aspirations! My love of my poor nature, for my grimy and slave-like but dear people, of my thatched village, of my country that you serve well or badly, but you serve yourself" (Korolenko, 1923, p. 188). But then he remembers a typical story of one Russian man in the U.S. whose nationality was identified by a Post Office clerk according to the manner of sticking stamps on the envelope. He was afraid that somebody might read his letter. Such a small thing shows how "confidence in everyday honesty develops together with the culture" (Korolenko, 1956).

Similar with M. Gorky, Korolenko's American experience was "a meeting with the city, with urban civilization" (Rougle, 1976). The permanent motif with the help of which Korolenko expresses the opinion of Matvey Lozinski, character of the story "Without a language," about the "foreign" world is the contrast of natural and cultural. Astonished by the technological power of the U.S., the character perceives them through the familiar and close to his images of nature.

In the essay "Russians at the Chicago crossroads," sharing his impressions of the Chicago exhibition, Korolenko observes that "the nature of the night was gone; there was only artificial light, stone, vanity, crowd and rumble" (Korolenko, 1923). But as the companions (Russians) were approaching the outskirts of the city, it became quieter and it was possible to guess that there, somewhere in God's faraway world, there was night, large, broad, thoughtful, boundless and mysterious" (Korolenko, 1923). The companions were shocked when they saw the moon, "street lights, lit windows, entrances, lighting ads, and amidst all this, like a really big lamp, there hung the moon prone to the sunset" (Korolenko, 1923).

The letters of Korolenko, of course, are dominated by the "intellectual's" point of view. As a writer and publicist, Korolenko drew attention to the biting headlines of the American newspapers (though, 
they later appeared in the early $20^{\text {th }}$ century in Russia). He writes to his wife about what is written in the American newspapers about Russia. For example, he is indignant at the judgment of Senator Edmonds who said that "the Russian nation is not worthy of institutions and, in general, it is sufficient of despotism. What a Russian-American friendship with this sort of considerations!" (Korolenko, 1956).

The latter view allows us to see in Korolenko's works not just ethnographic travel essays, but also deep reflection on the two images of the world-Russian and American, with an assessment of the pace of the technological progress, ideals of freedom, respect for the individual, attitude toward pragmatism, and individualism. Korolenko's attitude toward America is ambivalent. On the one hand, it can be characterized by the following confession in a letter to his wife, "leave Europe and America alone! Let them thrive, but we live better <...> There is really no better person in the world than a Russian person!” (Korolenko, 1956). In a letter to E. L. Ulanovskaya that was sent immediately after his return from abroad to Nizhny Novgorod, Korolenko wrote, "a Russian man feels bad in a foreign country, and, perhaps worst of all in America. It is really good and can be praised for many things, but it is not to our taste" (Korolenko, 1923). Therefore, the writer had no doubts that if he was offered to live in America or in Yakutsk region, he would choose the latter. On the other hand, it is "an amazing country!" (Korolenko, 1923).

Therefore, some kind of ideological dialogues are frequent in the travel notes. In the essay "Russians at the Chicago Crossroads," there is a conversation of some Russian immigrants one of whom is described as an acrimonious man, who, "according to the custom of almost all Russians, speaks about America and the Americans with great bitterness" (Korolenko, 1923). They talk about Russia, "about its small towns, wide fields, steppe roads, about its people, a leisurely and good-natured lifestyle" (Korolenko, 1956). One of the participants of the conversation calls the Americans callous people, however, their conversation comes to an unexpected conclusion: Russian's melancholy in a foreign land is a longing for justice which you cannot have in your homeland ("And there, where there is no justice, it is impossible to talk about love") (Korolenko, 1923).

The character of the story "Without a language" met some Jewish emigrants and the Poles. "They all work together to solve one problem: whether to accept a new culture or to preserve their own one. Peasant Matvey Lozinski, of course, stands for the strict observance of their own rules, manners and customs, and denies those who betray them. But this steadfast traditionalism has still cracked. There is little freedom in America, but there are conditions for the sprouts of freedom to survive. In Russia there are no such conditions yet" (Savelieva, 1998). It can be concluded that the image of the U.S. appears in the works of Korolenko more voluminous and ambiguous than is generally assumed. This fact has already been pointed out by American historians (Moser, 1969).

What Korolenko saw in America was deeply imprinted in his creative memory and then repeatedly "popped up" in a variety of circumstances, contexts, and transformed into artistic images and journalistic arguments.

\section{American theme in the pre-revolutionary journalism of V. G. Korolenko}

Korolenko repeatedly wrote on the American theme in his pre-revolutionary essays. In 1916, he published a satirical article "An American Jackson's opinion on the Jewish issue" in which he recalled his journey across the Atlantic and one arrogant American. There, satirically, he presented the images of the Americans, "the boasted sons of the beyond-the-Atlantic republic" (Korolenko, 2011). Attitude toward the Jewish issue becomes for Korolenko an occasion to reflect on human rights. The final conclusion of this satire was inspired by an ideological conversation back in 1893: "Love, like grace, spreads where it wishes to. Justice is a must like air for breathing” (Korolenko, 2011, p. 143-144). 
He also recalls the American trip in his article "An American judge about the Russian police" in which he joins the debate between the newspapers Russkiye Vedomosti, Kievskaya Mysl, and other periodicals on a reporter's story "We are not anyhow in Russia" published in the Chicago newspaper Tribune (it dealt with an American judge's exclaimation on the brutal manners of the local police, "What's going on? Are we in Russia?") (Korolenko, 2011, p. 161). As an essayist Korolenko does not follow the way of compulsory patriotic praise of the existing Russian orders. He believes that Russian writers cannot be united here. Comparing the state of human rights in Russia and the U.S., he does it in America's favor.

Providing terrible episodes of his journalistic experience- the way the police cracked down on a humble man in the street - the writer asks a question and answers it, "is anything similar possible in America? I do not think that there are no such beasts, but still nothing like this is possible there. First of all, you cannot break like that into an American man's house at night. Secondly, their police are not on duty at any time. $\langle\ldots>$ In short, there is no doubt that in Russia you can do a lot of other things that are absolutely impossible in America" (Korolenko, 2011, p. 165).

Korolenko's condemnation of nationalism is within this framework. In the article "A few thoughts about nationalism" he asks, "what is a Russian person? Our nationality is a fact; it is a primary one which we have had since our birth and it inevitably and directly imposes its mark on us. We are Russian because we were born in Russia, have been breathing its air since childhood, have been looking at its miserable, sad and sometimes beautiful nature, expressed our feelings by the sound of its voice, our first love and our first anger and all the other sensations we have given away to Russian people. This is a fact which, of course, cannot but affect our mood and behavior (Korolenko, 2015). But feeling yourself, your advantages and disadvantages "should not make us love and glorify the disadvantages simply because they are ours and deny other people's merits because they are the strangers' ones"... "And above all, a man, who in his heart has a true sense of national dignity, will not boast it to the detriment of others as well as he won't boast his 'reputation' that has not been doubted yet" (Korolenko, 2015). Korolenko called such people as "ultra-Russian patriots" (Korolenko, 2015).

On December 5, 1917, commenting on the student Leo Reztsov's letter published in the newspaper Freedom and Life (Reztsov switched from the White Guard to the Bolsheviks and compared Russia with a car driven by an insanely brave man), Korolenko says, "Our psychology, the psychology of the Russians, is a body without a skeleton, flabby and unstable. Russian people are said not to be religiously devout. But you cannot feel religion anywhere. Nothing 'is a sin.' It is with the people. The same is with the intelligentsia" (Korolenko, 2015). Korolenko attributed this typical characteristic to the "modernist" figure of the Bolshevik Minister Lunacharsky (Korolenko, 2015).

\section{Burning issues on the national character in the "Letters to Lunacharsky"}

In the "Letters to Lunacharsky" written shortly before his death, the theme of America and comparison of Russian and American lifestyles, different cultural traditions occur repeatedly. In his "Letter Two" he recalls his visit to the World Exhibition in Chicago in 1893 when major riots broke out after the exhibition caused by the unemployment. He quotes his compatriot, a Russian Jew, "They all should have come to terms first, and then come here with a decision. That would have made sense" (Korolenko, 1991). But Mr. Stonn, also Russian-born, a Marxist, says that it is absolutely impossible to start immediately the economy of a huge country on socialist principles.

Korolenko claims that Russia was not ready for a social revolution. He calls the Russian revolution Asian and to the greetings from the East he says, "Asia responds to what it feels native in us that is Asian" (Korolenko, 1991, p. 146). 
In "Letter Three" he again turns to the parallel (Russia and America as well as Europe) and raises a thorny issue on the Russian people being behind in the upbringing of moral culture, "the course of historical fate has played a magical and low-down trick with Russia... from the blind worship of autocracy and complete indifference to politics our people immediately stepped to... communism, at least, to municipal government. The morals remained the same and so did the habits and way of life" (Korolenko, 1991, p. 150).

In "Letter Four" Korolenko predicts that "the European proletariat did not follow you and their prevailing mood is the mood of the American socialist Stonn whose opinion I mentioned in the second letter" (Korolenko, 1991, p. 156). He tries to dispel the rooted mythological ideas about the essential characteristics of the people, "In the transition to this future from the present, not all is subject to destruction and defeat. Such things as freedom of thought, assembly, speech and press are not just 'bourgeois prejudices' for them but necessary tools of the future, a kind of palladium, which mankind extracted in long and fruitful struggle and progress. Only we, who have never quite known these freedoms and have not learned to use them together with the people, declare them 'bourgeois prejudices' as they hamper the cause of justice. This is our grave mistake that again and again reminds of the Slavophile myth about our 'God-bearing people' and of our typical national fairy tale about Ivanushka, who, knowing no science, surpassed all sciences and who does everything without effort, as if by magic" (Korolenko, 1991, p. 156-157). According to Korolenko, "you must not love people as a community convenient for experiments but as they are in reality" (Korolenko, 1991, p. 159).

Again, there is an argument in the letter based on the American experience, "For example, when I was travelling around America, I was pleased to think about the impossibility of the Lynch Law in our country. At that time a case broke out in one of the southern states: a black man raped a white girl and to conceal the crime he killed her. The population of the town assembled a [legal] court, and burned him alive. <...> I think that even now, during the greatest brutality, such a phenomenon is impossible. The Slavic mentality of our people is gentler than the Anglo-Saxon one!" (Korolenko, 1991, p. 150).

And yet the writer, having lived long and knowing Russia and Russian traditions well, sadly notes that "in America the moral culture is considerably higher," although "by mentality, by inborn abilities, our people are equal with the best nations of the world, and this makes us love them." (Korolenko, 1991, p. 160-161). Resorting to the "natural" comparison, Korolenko says, "from such material as carbon you can get both lovely diamond crystals and amorphous coal. So, there is some difference in the internal structure of the atoms. The same can be said about the human atoms that make up society: not every form can be instantly crystallised from a given society. In many cities of Switzerland you can safely leave anything on the boulevard, and, upon returning there, find it in the same place. And in our country - let's speak openly...” (Korolenko, 1991, p. 161).

It was the writer's hard-won position. Even during the first Russian revolution, after the Manifesto of October 17, 1905, he, having faced the manifestations of mass psychology that took the form of pogroms in towns and villages, wrote about the necessity for a long-term training of simple public spirit and autonomy. The theme of national self-criticism, together with Korolenko, was also shared by M. Gorky and I. A. Bunin and in the $19^{\text {th }}$ century by P. Ya. Chaadayev and V. S. Soloviev. Around the same time M. Gorky in a now forgotten article "On Civic Education" (1918) wrote, "we always have plenty of 'focuses', but we haven't got the best one - a focus on ourselves, on our own strength. A Western citizen, on the contrary, is used to focusing on themselves, and having started this focus by struggling against the feudal lords, perfectly finished it by the Great Revolution. Our urban residents took part in the political fight only once, in the Time of Troubles, and having overcome countless enemies, immediately gave up their legal rights and obligations to the land nobility, shattered and disfigured by the 'devastation"” (Gorky, 1990). 


\section{Conclusion}

It is difficult to attribute Korolenko to any particular school of social thought, but it is obvious (this is also proved by previously little-known texts) that the tragic events of the revolutionary years, perceived morally and aesthetically through the writer's inherent attraction to the principles of equity, duty, law, order, and respect for the individual increased his critical attitude toward national mentality. Korolenko's essays continue the best traditions of Russian social thought. His later comments about the national character were successive to the ideas of Petr Chaadaev. The outstanding writer's comments made by him in the latter days of his life have not, unfortunately, lost their relevance and sound unflattering about the national identity. But the question of whether he considered the negative qualities of a national identity inherent in the people, or brought by some external factors, remains open and requires further study.

\section{References}

Anderson, B. (1993). Imagined Communities: Reflections on the Origin and spread of Nationalism. London.

Arustamova, A. A., \& Kondakov, B. V. (2010). Konstanta "Amerika” v russkoy literature XIX veka [Constant "America" in Russian literature of the 19th century]. Russian and Foreign philology, 5(11), 111-120. Perm: Bulletin of Perm State University.

Bhabha, H. (Ed.) (1990). Nation and Narration. London.

Franklin, S., \& Widdis, E. (2014). Vse Rossii ili vsya Rus [All of Russia or All Russia]. Political Encyclopedia, 19. Moscow: National identity in Russian culture.

Gorky, M. (1990). O grazhdanskom vospitanii [About civic education]. Literature issues, 4, 273.

Korolenko, V. G. (1923). Polnoye sobraniye sochineniy. Posmertnoye izdaniye. Neizdanniye proizvedeniya [Complete Works. Posthumous publication. Unpublished works] (Vol. XVIII). Kharkov: Ukrain's State Publishing House.

Korolenko, V. G. (1956). Sobraniye sochinenii v 10 tomakh [Complete works in 10 volumes] (Vol. 10). Letters 1879-1921. Moscow: Fiction State Publishing House.

Korolenko, V. G. (2015, March 7). Neskolko mysley o natsionalizme [Some thoughts about nationalism]. Retrieved from http://az.lib.ru/k/korolenko_w_g/text_1100.shtml

Korolenko, V. G. (2015, March 2). Dnevnik 1917-1921 gg [Diary of 1917-1921]. Retrieved from http://az.lib.ru/k/korolenko_w_g/text_1921_dnevnik.shtml

Korolenko, V. G. (1991). Zemli! Zemli! Zemli! [Lands! Lands! Lands!]. Moscow: Soviet writer.

Moser, Ch. (1969). Korolenko and America. In Russian Review An American Quarterly Devoted to Russia Past and Present, $28(3), 303$

Neizdanniy V. G. Korolenko [Unpublished V.G. Korolenko](2011). Political Essays 1914-1916 (Vol. 1). Moscow.

Rougle, C. (1976). Three Russians consider America: America in the works of Maxim Gorky, Aleksandr Blok and Vladimir Majakovskij. Stockholm.

Saul, N. E. (1991). Distant friends: the United States and Russia, 1763-1867. Lawrence, Kan.

Savelieva, E. G. (1998). Amerikanskiye vpechatleniya V.G. Korolenko i povest "Bez yazyka" [V.G. Korolenko's impressions of America and the story "Without a Language"]. St. Petersburg State University Herald, 1(2), 90. 